\title{
Not in our park! Local community perceptions of recreational activities in peri-urban national parks.
}

To cite this article:

Rossi, S. D., Pickering, C. M., \& Byrne, J. (2016). Not in our park! Local community perceptions of recreational activities in peri-urban national parks. Australasian Journal of Environmental Management. Doi: 10.1080/14486563.2015.1132397.

To link to this article: $\mathrm{http} / / / \mathrm{dx}$.doi.org/10.1080/14486563.2015.1132397

\begin{abstract}
Increased pressure to allow more recreational activities in peri-urban national parks may impact local communities. We surveyed residents living in local communities near six peri-urban national parks (IUCN Category II) in Queensland, Australia. We assessed their sense of place, their perceptions of different types of visitors' activities, and interactions between attitudes and perceptions. Most respondents, including national park users and non-users, perceived non-motorized recreational activities as appropriate but perceived motorized activities negatively. Overall, negative perceptions were related to a respondent's sense of place. Respondents with a stronger sense of place had more positive perceptions of non-motorized activities but more negative perceptions of motorized activities than respondents reporting a weaker sense of place. Results suggest that people identifying with their local national park may have a small 'latitude of acceptance' for motorized activities. We found limited displacement due to recreational conflicts; most respondents still visited these parks. The methods used here, if applied to other peri-urban national parks, could help determine a local community's recreational activity thresholds, offering park managers a way to potentially diminish conflict and enhance visitors' experiences.
\end{abstract}

Keywords: park non-users, community perceptions, sense of place, conflict, local visitors, social judgment theory

\section{Introduction}

Should everyone be welcome in national parks, or are there some activities that just do not belong in these multi-purpose green spaces? Demand for access to many types of protected areas close to urban areas is increasing. This is in part due to rapid urban growth and concomitant pressure for a range of recreational activities in protected 
areas, such as mountain biking and horse riding (Pickering; Rossi \& Barros 2011). In some cases, new protected areas have been declared at the peri-urban fringe of cities on land previously used for extractive industries (e.g. logging), and in places where high-impact recreation activities were permitted in the past (Lawton \& Weaver 2008, Rossi, et al. 2013). In Australia, this includes areas that are now IUCN Category II National Parks, which aim to protect natural biodiversity and ecosystem process and afford environmentally sustainable recreational opportunities (Worboys, et al. 2015). Here, the appropriateness of a range of recreational activities is often contested, in part due to differences in people's perceptions of the social and environmental impacts of these activities (Pickering, et al. 2011), but also due to how people perceive the purpose of these types of parks.

Protected areas, including peri-urban national parks, are the primary tool for nature conservation globally (Worboys, et al. 2015). They also often provide opportunities for a range of tourism and recreational activities (Balmford, et al. 2009, Lockwood, et al. 2006, Vaske, et al. 2007). Communities living close to protected areas such as national parks can be affected by the presence and management of these areas (Lockwood, et al. 2006), including the types of recreational activities that are permitted within these green spaces (Jurowski \& Gursoy 2004, Lockwood, et al. 2006).

Although the activities permitted in these settings are based on IUCN Category II objectives, enforced through legislation and regulations, it is important to understand how local communities perceive the appropriateness of different recreational activities. Social conflicts can arise within local communities about which activities should be permitted in nearby protected areas. This includes whether the activity is perceived to be compatible with the conservation goals of the park and/or with diverse recreational activities. In some cases, this can result in visitor displacement, where some people do not use their local national park because park activities negatively affect them (Arnberger \& Haider 2005, Bentrupperbäumer \& Reser 2008). In other cases, it may increase local resident dissatisfaction with park management. These issues can potentially limit the benefits that local residents derive from regular access to parks, such as health and wellbeing associated with active lifestyles (Byrne, et al. 2009, Peschardt, et al. 2012). 
While scholars have found that regular access to parks (including national parks) is important, few studies have investigated constraints to peri-urban national park visitation faced by local communities (Frick, et al. 2007, Lawton \& Weaver 2008). Even fewer studies have investigated local residents' attitudes towards national parks or their perceptions of the appropriateness of different recreational activities undertaken in peri-urban national parks. Nor have studies assessed how in turn this might affect local residents' park (non)use choices (Frick, et al. 2007, Lawton \& Weaver 2008, Zanon, et al. 2013). This article reports the findings of research that examined the sense of place of local residents and their perceptions of appropriate park activities, in communities near peri-urban national parks in South East Queensland, Australia. It included people who used and did not use peri-urban national parks.

The article addresses three questions: (1) How do residents of local communities perceive different recreational activities in peri-urban national parks? (2) Are their perceptions of the appropriateness of different recreational activities affected by socio-demographic characteristics and their sense of place, and if so, how? and (3) Do these perceptions differ between users and non-users of these parks? The first section of this manuscript concisely examines interrelated constructs, including perception, attitudes and 'sense of place'.

\section{Attitudes}

Attitudes can be defined as 'a learned predisposition' towards an object or situation, or to paraphrase Fishbein \& Ajzen (1975), how an individual responds to an object, person, behavior or policy in a 'consistently positive or negative manner' (Ajzen \& Fishbein 1977, p. 888, Fishbein 1963, Fishbein \& Ajzen 1975). Attitudes are influenced by people's values (Axelrod 1994) and also mediate a person's perceptions (Rossi, et al. 2015), depending upon 'situational cues', the strength of the attitude, and whether the attitude is positive or negative (Figure 1) (Fazio \& Williams 1986, Jorgensen \& Stedman 2006). Attitude-behavior responses appear to be driven by emotional (affective) and rational (cognitive) psychological processes.

\section{Perceptions}

The term perception refers to cognition-processes that are related to how a person interprets external information or stimuli to make sense of the external world (Hofmann, et al. 2012, Lemberg 2010, Rossi, et al. 2015). Psychologists recognize 
that perceptions are typically mediated by a range of factors including: individual personality traits, socio-demographic characteristics, attitudes, beliefs, knowledge, social norms, personal values and expectations (Dietz, et al. 2005, Fazio 1990, Knafo, et al. 2011, Reser \& Bentrupperbäumer 2005). Importantly, numerous studies have found that a person's attitudes affect their perceptions, coloring their assessment of situations and acting as a type of filter through which the word is apprehended (Fazio 1990).

\section{Sense of place}

In human geography, how people respond to the environmental qualities of a particular place is often referred to as their 'sense of place' (Buttimer \& Seamon 1980, Relph 1976, Tuan 1980). For geographers, spaces become places when people inscribe them with meaning and/or instill them with social values (Tuan 1977). In environmental psychology, the term 'place attachment' has been used to refer to a similar idea (Inglis, et al. 2008, Williams \& Vaske 2003). According to Jorgensen and Steadman (2001), a sense of place 'is not imbued in a physical environment, rather it resides in the human interpretations of the setting'. Sense of place is a type of attitude (Jorgensen \& Stedman 2001, Lee 2011, Tuan 1974, Tuan 1977).

The sense of place attitudinal construct is said to be comprised of three dimensions: 'place identity', 'place attachment' and 'place dependence' (Jorgensen \& Stedman 2006). Place identity refers to an individual's personal beliefs about how they are 'invested in a particular spatial setting' (Williams \& Vaske 2003). Place attachment refers to an individual's 'emotional connection' to a place. Place dependence refers to the advantages that a place offers an individual relative to other places (e.g. in supporting their motivations or behavioral objectives - such as recreational activities). These definitions draw upon the psychological understanding that an: 'attitude reflects a person's evaluative feelings towards an object', which in our study is a national park (Jorgensen \& Stedman 2006, Williams \& Vaske 2003).

Many researchers have used the terms 'sense of place' and 'place attachment' interchangeably (Lewicka 2011, Lin \& Lockwood 2014), creating ambiguity in how these terms should be operationalized. For the purpose of this article, the term 'sense of place' refers to an attitude, and is operationalized using the Williams \& Vaske (2003) psychometric scale. This scale contains measures of place dependence and place identity - thus avoiding the conflation of place attachment and sense of place, 
which troubles some other studies (Kyle, et al. 2004) (see Figure 1). In this article we use social judgment theory to examine how people's affinity for, and attachment to, these places shapes their perceptions of activities which they consider as belonging or inappropriate in national parks, and in turn their park-use choices (Kyle, et al. 2004, Stedman 2002).

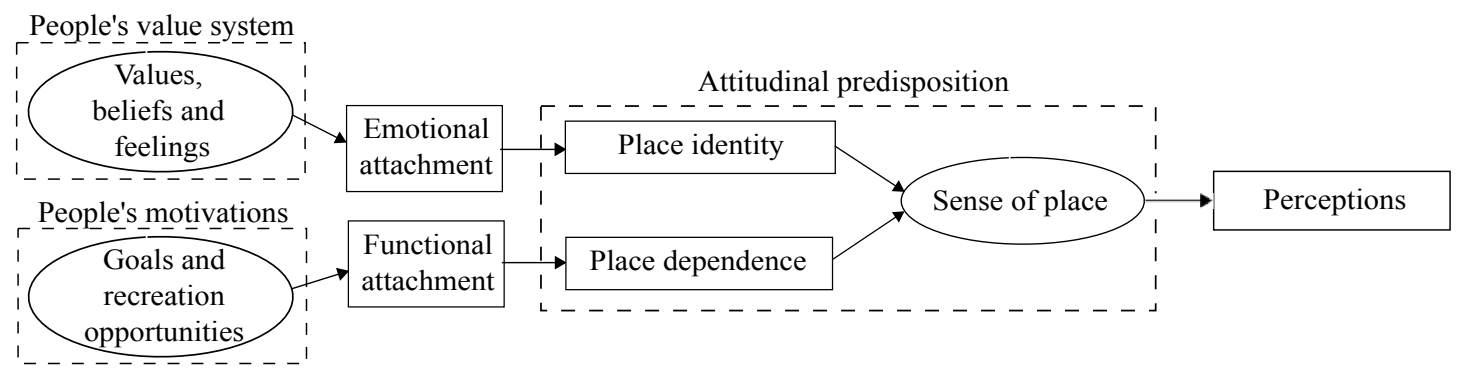

Figure 1. Simplified conceptual model of people's relationships with places and the construct of sense of place based on information from Kaltenborn (1998), Kyle, et al. (2004), Larson, et al. (2013), Lin \& Lockwood (2014) and Williams \& Vaske (2003). People's values and motivations influence their attitudes, which will influence their perceptions (Fishbein 1963, Hsu, et al. 2010, Schwartz 1994).

\section{Social judgment theory}

To better understand how people's sense of place (attitudes) can influence their perceptions about social and environmental impacts, Kyle, et al. (2004) used 'social judgment theory'. This theory, developed by Sherif \& Hovland (1961), establishes a relationship between peoples' attitudinal position and their perceptions of new information or situations (Kyle, et al. 2003, Kyle, et al. 2004).

The social judgment theory posits that we judge information based on a categorization 'spectrum' along which our attitudinal position is anchored (Kyle, et al. 2004, O'Keefe 2008). This categorization spectrum consists of our latitude of acceptance, our latitude of rejection and our latitude of non-commitment ${ }^{1}$. (Kyle, et al. 2004, O'Keefe 2008). The theory establishes that our attitudinal position within these different latitudes will influence our perception (O'Keefe 2008). It also establishes that the intensity of the anchoring is related to our ego-involvement (i.e. "belonging to

\footnotetext{
${ }^{1}$ For this study people's latitudes of acceptance, rejection or non-commitment were not measured. Rather, the social judgment theory was used to understand how people's sense of place can influence their perceptions about different recreational activities.
} 
me" and "being part of me") as suggested by Sherif \& Cantril (1947, pp. 93), which defines the range of our latitudes (Kyle, et al. 2004).

In accordance with other studies, that defined sense of place as an attitude (Jorgensen \& Stedman 2001, Kyle, et al. 2004), the position adopted in this article is that the intensity of different sense of place dimensions referred to earlier (e.g. high -or lowplace identity) will influence a person's positive or negative perceptions of the appropriateness of different activities undertaken in peri-urban national parks. For instance, a strong positive attitude towards an object will define a large latitude of acceptance of that object (Kyle, et al. 2004, O'Keefe 2008). Previous studies have found that people holding a strong sense of dependence reported higher levels of tolerance or a 'wider' latitude of acceptance to social and environmental impacts (Kyle, et al. 2004). We mobilize this theoretical frame when discussing our results, later in the article.

\section{Methods}

\section{Study area}

This study was conducted in six peri-urban national parks within the south-eastern region of Queensland, Australia (Figure 2). Queensland has a population of over four million people, with around 65 per cent living in the more urbanized south-eastern corner of the State, in and around Brisbane, the Gold Coast and the Sunshine Coast (ABS 2014). National parks close to these urban areas provide diverse recreational opportunities for local communities. Many of these activities occur on multiple use trails in the larger parks including walking, running, cycling and horse riding (Rossi, et al. 2013). In recent years, the conservation status of these areas has changed from government owned and managed commercial forest (State Forest) to national park (Rossi, et al. 2013). This change in status has resulted in regulation changes about visitor use in these protected areas, as well as planning and management priorities and strategies $^{2}$ (DERM 2011, Rossi, et al. 2013).

\footnotetext{
2 To assess the social and environmental impacts of different types of visitor activities in these parks, the Queensland Government established a long term monitoring program (DERM 2011). The current study is part of this broader visitor monitoring program, and provided an opportunity to assess residents' perceptions about their local park and its use for different recreational activities (Rossi, et al. 2013).
} 


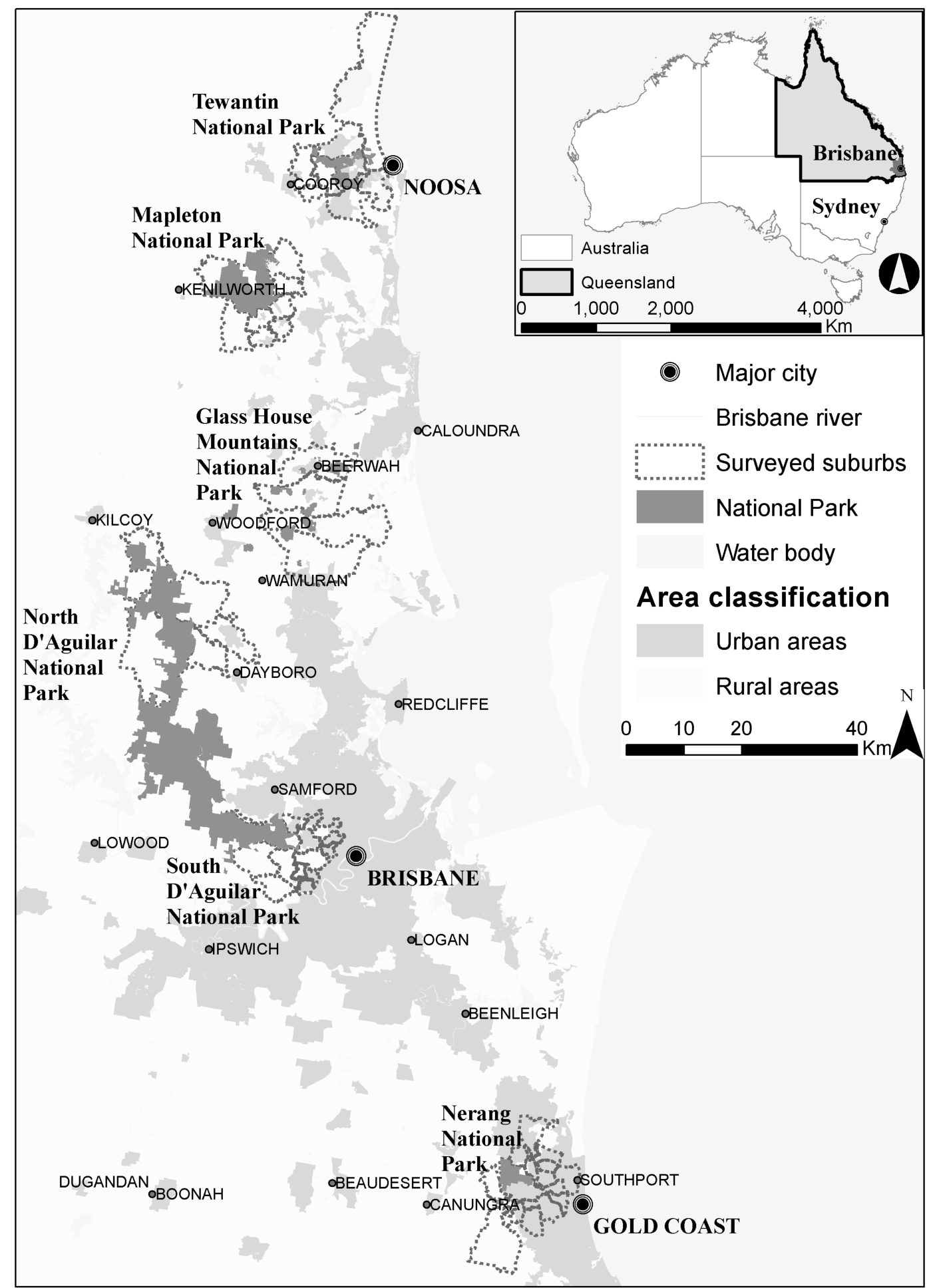

Figure 2. The six national parks that are the focus of this study and the adjacent local communities that were surveyed. The parks are (from North to South) Tewantin National Park, Mapleton National Park, Glass House Mountains National Park, North D'Aguilar National Park, South D'Aguilar National Park and Nerang National Park. 


\section{Study sites}

This study examined the perceptions of local communities around six national parks close to large urban areas in south-eastern Queensland: Tewantin, Mapleton, Glass House Mountains, D’Aguilar and Nerang National Parks (Figure 2). These parks vary in size from 1,700 ha to 40,000 ha. They were all once used for commercial logging, as well as for a range of recreational activities, including four-wheel driving and trail bike riding, prior to their designation as 'National Park' (DERM 2011, Rossi, et al. 2013). In two of these national parks: Mapleton National Park and D'Aguilar National Park, motorized activities are still permitted, while horse riding is permitted in all of them, but only on forest reserve trails within the parks (DERM 2011, Rossi, et al. 2013). Although motorized activities are not permitted in the other three parks, they still occur (pers. obs). Visitation to the six parks consists almost exclusively of local visitors with only 22 per cent of people travelling further than $50 \mathrm{~km}$ (Rossi, et al. 2015, Rossi, et al. 2013).

\section{Data collection}

A postal mail-return survey of households within neighborhoods surrounding the parks was used to obtain information about resident's perceptions of different recreational activities within their local national park. Veal (2011) suggests that postal mail surveys, telephone surveys and in-person household surveys have advantages and disadvantages. They may all have low response rates and other potential sources of bias. For example, with the shift from households having landline telephones to mobile telephones it is more difficult to obtain geographically based samples using telephone surveys (Veal 2011). Postal mail surveys are often the least expensive of the three methods and can provide clear geographical defined samples, but they can have low response rates and may oversample older people, potentially more familiar with an issue and with more time to respond to a survey (Dillman 2007). In-person surveys can produce better response rates, but are typically more expensive and also have a tendency to oversample older individuals and those who are more likely to be at home (Veal 2011). For these reasons a postal survey was used.

The first stage in the mail survey process involved selecting households in local areas around the target national parks (suburbs). A map showing five $\mathrm{km}$ buffers around the main entrances to each of the six national parks was produced using ArcGIS ${ }^{\circ}, \mathrm{V} 10.1$. The buffer area was based on the average distance that people travel to local 
amenities, which is typically $<5 \mathrm{~km}$ (Haugen \& Vilhelmson 2013). A shapefile of suburbs (QDNRM 2012) that were intersected by the buffer areas was created for each park (Figure 2). The residential addresses and contact names of 81,239 residential households within the selected suburbs were extracted from a commercial database of residential addresses, purchased from 'CustomLists.net' and imported into the Statistical Package for Social Science (SPSS ${ }^{\circ}$ V21).

To obtain a representative minimum sample size of at least 380 responses, required to ensure a 95 per cent confidence interval for the survey (Veal 2011), a total of 5,000 households were randomly selected from the 81,239 households database. To ensure that all households in these localities were equally likely to be selected, a stratified random selection process was used (Veal 2011). More than six per cent of all households around each park were sent a survey. Consequently, more surveys were sent to suburbs with more households.

Following the Dillman (2007) method, for each of the 5,000 households selected, a survey package was posted to a named resident at that household. The survey package contained an introductory letter, an information sheet including consent to participate in the survey, a reply-paid envelope and the questionnaire. The questionnaire was individualized for each park, including a map of the park, to enable households to respond to questions regarding their local national park. From the 5,000 packages originally mailed out, a total of 392 people returned the completed survey, exceeding the minimum sample size required to ensure a 95 per cent confidence interval (Veal 2011).

\section{Survey instrument}

The survey included 12 questions adapted from a previous instrument used to examine people's perceptions about national parks and visitation patterns in the USA and Australia (Byrne, et al. 2009, Healy 2009). Measures in that instrument have proved to be robust, reliable and valid. To gather local residents' socio-demographic information (sex, level of education and age) and park usage patterns, closed questions were used. For information about householders' perceptions about recreation activities in their local national park, respondents were asked to identify how positively, neutrally or negatively a series of activities (mountain biking, hiking, running, horse riding, picnicking, dog walking, trail bike riding and four-wheel driving) impacted upon them. To gather visitor perceptions of the environmental and 
social impacts of different recreational activities in the parks, respondents were asked to complete a multiple option question. This question requested them to indicate, for each activity that they selected as negatively affecting them, what adverse impacts they perceived or had personally experienced (i.e. potential collisions or injury, traffic, too noisy, startle people, damage plants or animals, frighten wildlife, leave animal waste, and create litter).

To gather information about people's sense of place in relation to their local national park, a psychometric scale developed by Williams \& Vaske (2003) was used. This scale has been tested in a range of situations, including to assess the sense of place of local communities, and has proved to be robust and reliable (Williams \& Vaske 2003). This question assessed 12 items, measured on a five-point Likert scale (Table 1). To determine respondents' sense of dependence and identity with their local national park, a reliability test of the 12 items (six items for each 'identity' and 'dependence') was conducted. The six items for sense of identity had high reliability (Cronbach's $\alpha>0.95$ ) as did the sense of dependence measures, which were reduced to five reliable items (Cronbach's $\alpha>0.90$ ).

Table 1. Items of the psychometric scale used to measure people's sense of place. Mean of the five point likert scale question ranging from $-2=$ strongly disagree to $2=$ strongly agree and factor analysis matrix of items loading in the two components (sense of identity and sense of dependence).

\begin{tabular}{lccc}
\hline \multirow{2}{*}{ Psychometric items } & Mean & \multicolumn{2}{c}{ Sense of place } \\
\cline { 3 - 4 } & & Sense of identity & Sense of dependence \\
\hline I feel like [park name] is a part of me & 0.28 & 0.851 & \\
[park name] is very special to me & 0.43 & 0.913 & \\
I identify strongly with [park name] & 0.16 & 0.908 & 0.803 \\
I am very attached to [park name] & 0.19 & 0.921 & 0.839 \\
Visiting [park name] says a lot about who I am & -0.10 & 0.814 & 0.885 \\
[park name] means a lot to me & 0.44 & 0.907 & 0.884 \\
[park name] is the best place for what I like to do & 0.22 & & \multirow{2}{*}{0.794} \\
No other place can compare to [park name] & -0.24 & & \\
I get more satisfaction out of visiting [park & -0.32 & & \\
name] than from visiting any other park & & & \\
Doing what I do in [park name] is more & -0.23 & & \\
important to me than doing it in any other place & & & \\
I wouldn't substitute any other area/place for & -0.27 & & \\
doing the types of things I do in [park name] & & &
\end{tabular}

\section{Data analysis}

Data from the completed surveys were transferred into the Statistical Package for the Social Sciences (SPSS ${ }^{\circledR}$ V21). Descriptive statistics, including frequencies, case 
summaries and cross tabulations for variables were calculated. To assess relationships among variables, a series of Categorical Principal Component Analyses (CATPCA) were conducted. The CATPCA is analogous to Linear Principal Component Analysis (PCA), except that it is suitable for the analysis of categorical variables (nominal or ordinal) and non-linear relationships. In CATPCA, variables categories are transformed into numerical values and then analyzed as conventional linear PCA (Linting, et al. 2007).

The CATPCAs were used to assess the relationship between local community sociodemographic characteristics and usage patterns, their sense of place towards their local national park, and their perceptions about recreational activities. To conduct these analyses, recreational activities were divided into motorized (trail bike riding and four-wheel driving) and non-motorized activities, while people's sense of place was differentiated between sense of identity and sense of dependence. These analyses were conducted in three steps: (i) the local community as a whole and then for specific comparisons including between (ii) park users and non-users, and then for (iii) frequent users ( $>$ five times a year) vs non-frequent users ( $<$ once a year). In addition, a CATPCA analysis was conducted to examine the relationship between park usage (user/non-user) and perceptions towards each recreational activity (i.e. mountain bike riding, horse riding, dog walking, picnicking, running, hiking, trail bike riding and four wheel driving).

For all CATPCA analyses, local community characteristics (i.e. socio-demographics, users/non users, frequent/non-frequent visitors) were considered as nominal variables and sense of place and perceptions were considered as ordinal variables. In addition to the CATPCA analyses, Chi-Squared (' $\chi$ ' statistics), Mann-Whitney (' $U$ ' statistics) and Kruskal-Wallis ('H' statistics) tests were used to examine differences within the relationships identified by the CATPCAs.

\section{Results}

Results are presented in two sections. First, socio-demographic characteristics, perceptions of different recreational activities, and sense of place towards peri-urban national parks are analyzed for local communities. Second, a comparison based on park usage, between user and non-user characteristics is presented. 


\section{Local communities}

\section{Socio-demographic characteristics}

Equal proportions of males and female responded the survey (Table 2). Most respondents were over 45 years old (83\%) with only five per cent under 34 years old. Respondents were well educated, with 57 per cent holding a university degree or equivalent, while 34 per cent had completed secondary, vocational or technical education and just 10 per cent had only completed primary or some secondary education. Two thirds of respondents visited their local park (68\%); many of who were frequent visitors $(69 \%)$ (Table 2$)$. The most popular recreational activity was hiking (63\%). Other reported activities included mountain bike riding (7\%), picnicking (7\%), sightseeing (6\%) and running (5\%) with less common activities $(<$ $3 \%$ ) including dog walking, photography and horse riding.

Table 2. Characteristics of respondents to a mail survey of local communities near six national parks in South East Queensland, Australia. Differences between park users and non-users were assessed. Values in bold are significant at $\alpha=0.05$.

\begin{tabular}{lccccc}
\hline \multicolumn{1}{c}{ Total } & Users & Non-users & Test & P \\
\hline Respondents & $\mathrm{N}=392$ & $68 \%$ & $32 \%$ & & \\
Frequent visitors & $\mathrm{N}=185$ & $69 \%$ & & & \\
Non-frequent visitors & $\mathrm{N}=83$ & $31 \%$ & & & \\
Socio-demographic characteristics & $\mathrm{N}=381$ & $\mathrm{~N}=262$ & $\mathrm{~N}=119$ & $\chi^{2}=0.795$ & 0.373 \\
$\quad$ Sex & $50 \%$ & $51 \%$ & $46 \%$ & & \\
$\quad$ Male & $50 \%$ & $49 \%$ & $54 \%$ & & \\
$\quad$ Female & $\mathrm{N}=389$ & $\mathrm{~N}=268$ & $\mathrm{~N}=121$ & $\chi 2=8.808$ & $\mathbf{0 . 0 0 3}$ \\
Education & $43 \%$ & $38 \%$ & $55 \%$ & & \\
$\quad$ technical degree & $57 \%$ & $62 \%$ & $45 \%$ & & \\
$\quad$ University degree & $\mathrm{N}=390$ & $\mathrm{~N}=268$ & $\mathrm{~N}=122$ & $\mathrm{H}=0.165$ & 0.684 \\
Age & $2 \%$ & $1 \%$ & $2 \%$ & & \\
$\quad<24$ & $3 \%$ & $3 \%$ & $3 \%$ & & \\
$25-34$ & $13 \%$ & $13 \%$ & $13 \%$ & & \\
$35-44$ & $23 \%$ & $24 \%$ & $20 \%$ & & \\
$45-54$ & $60 \%$ & $59 \%$ & $62 \%$ & & \\
$>55$ & $\mathrm{~N}=377$ & & & & \\
Sense of place & $0.24 \pm 0.04$ & $0.51 \pm 0.04$ & $-0.39 \pm 0.07$ & $\mathrm{U}=23,909$ & $<\mathbf{0 . 0 0 1}$ \\
Identity & $-0.16 \pm 0.04$ & $-0.02 \pm 0.04$ & $-0.48 \pm 0.07$ & $\mathrm{U}=19,114$ & $<\mathbf{0 . 0 0 1}$ \\
Dependence & & & & & \\
\hline \multicolumn{7}{l}{}
\end{tabular}

\section{Perceptions of different recreational activities}

Generally most respondents' perceptions of non-motorized activities such as mountain bike riding, dog walking, horse riding or running were positive (Table 3), while negative perceptions were commonly reported for motorized activities, such as trail bike riding and four wheel driving (62\% for each, Table 3). Respondents' perceptions differed based on their age, but not based on their sex or education. Older 
people reported being more negatively affected by motorized activities than their younger counterparts $(H=17,885, p<0.001$; Figure 3$)$.

Table 3. Perceptions of the local communities near six national parks in South East Queensland about motorized and non-motorized activities. Values in bold are significant at $\alpha=0.05$.

\begin{tabular}{|c|c|c|c|c|}
\hline & Users & Non-users & Mann- & $\mathrm{P}$ \\
\hline & \multicolumn{2}{|c|}{ Mean \pm S.E. } & Whitney & $P$ \\
\hline Perceptions about activities & & & & \\
\hline Non-motorized (among all respondents) & \multicolumn{2}{|c|}{$0.43 \pm .04$} & & \\
\hline Non-motorized & $0.50 \pm .04$ & $0.09 \pm .05$ & 19,969 & $<0.001$ \\
\hline Hiking & $1.11 \pm .05$ & $0.33 \pm .07$ & 20,446 & $<0.001$ \\
\hline Running & $0.77 \pm .05$ & $0.23 \pm .07$ & 18,019 & $<0.001$ \\
\hline Picnicking & $0.85 \pm .05$ & $0.17 \pm .07$ & 19,345 & $<0.001$ \\
\hline Mountain biking & $0.11 \pm .07$ & $-0.11 \pm .07$ & 15,390 & 0.086 \\
\hline Horse riding & $0.09 \pm .05$ & $-0.07 \pm .06$ & 14,864 & 0.160 \\
\hline Dog walking & $0.12 \pm .07$ & $-0.04 \pm .07$ & 15,000 & 0.159 \\
\hline Motorized (among all respondents) & \multicolumn{2}{|c|}{$-0.57 \pm .03$} & & \\
\hline Motorized & $-1.09 \pm .06$ & $-0.50 \pm .08$ & 9,130 & $<0.001$ \\
\hline Trail bike riding & $-1.10 \pm .06$ & $-0.48 \pm .08$ & 9,036 & $<0.001$ \\
\hline Four wheel driving & $-1.06 \pm .06$ & $-0.51 \pm .08$ & 9,531 & $<0.001$ \\
\hline
\end{tabular}

\section{Sense of place}

As noted earlier, sense of place is an attitude. We assessed two dimensions of this attitude - sense of identity and sense of dependence. Overall, respondents who appeared to hold an emotional or symbolic relationship with their local national park reported a positive sense of identity (Mean $=0.24 \pm 0.04$; Table 2). In contrast, respondents reported an overall negative sense of dependence on their local park (Mean $=-0.16 \pm 0.04$ ), suggesting that they do not have a functional or goal-directed relationship with these parks (Table 2). The sense of dependence differed between men and women, with males reporting less sense of dependence than women $(\mathrm{U}=$ $13,939, \mathrm{p}=0.005$; Figure 3). Also, respondents' sense of dependence and identity differed based on their age, with those between 25 and 34 years old reporting lower dependence $(H=10,517, p=0.033)$ and identity $(H=10,145, p=0.038)$ than others, although only 11 respondents were between 25 and 34 years old (Figure 3 ).

As expected, the multivariate analysis, CATPCA, showed that there was an interaction effect between respondents' sense of place and their perceptions of recreational activities in their local national park (Cronbach's $\alpha=0.82$; Figure 3). People identifying with these parks reported positive perceptions of non-motorized 
activities but were negatively affected by motorized activities. Although respondents reported no sense of dependence on their local national park overall, a non-significant trend similar to that for sense of identity was identified. For instance, on the one hand, respondents reporting a greater sense of dependence perceived non-motorized activities positively and motorized activities negatively (Figure 3). On the other hand, people holding negative sense of dependence and identity reported more positive perceptions of motorized activities and tended to hold neutral or more negative perceptions about non-motorized activities (Figure 3).

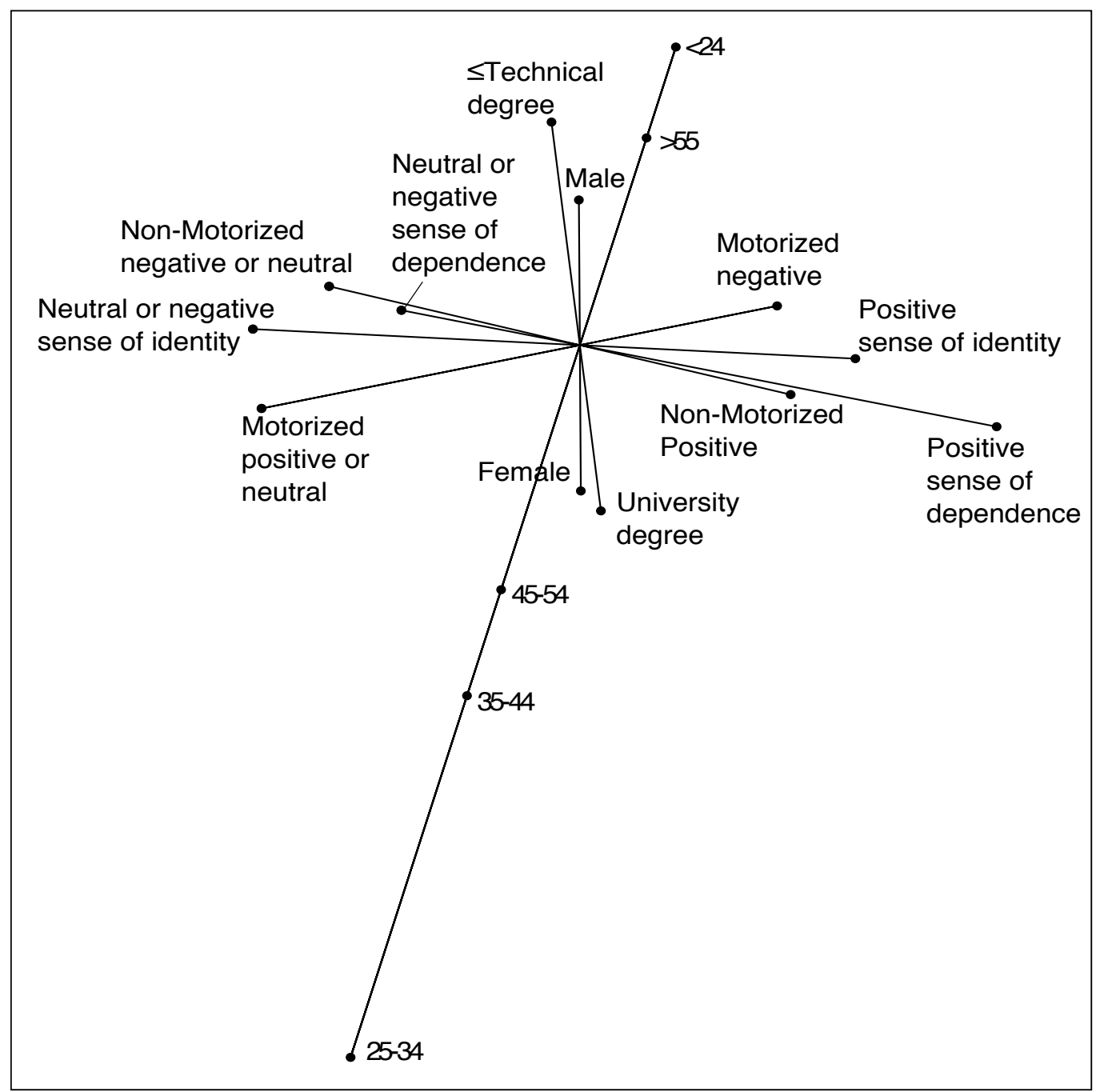

Figure 3. Categorical principal component analysis of local communities' characteristics, sense of place and perceptions about their local national park in South East Queensland, Australia. The projection of the variables shows the relationship among them, with variables close together positively related and variables at $90^{\circ}$ angle not related to each other. Level of education includes: (i) $\leq$ technical degree comprised by people who completed primary and/or have some secondary education, completed secondary, vocational or technical education and (ii) university degree consisting of people who completed a university degree. 


\section{Park usage}

\section{Socio-demographic characteristics}

Respondents who used the local national parks differed from non-users in their level of education, with users more likely to have a higher level of education than non-users $\left(\chi^{2}=8.808, \mathrm{p}=0.003\right.$; Table 2$)$. There were no differences in the proportion of men and women, or ages, among users and non-users (Table 2). There were no differences in socio-demographic characteristics between frequent and non-frequent users including age, sex or education.

\section{Sense of place}

The multivariate analysis (CATPCA) shows that park users' sense of place differed from non-users in relation to their local national park (Cronbach's $\alpha=0.89$; Table 2, Figure 4a). As would be expected, park users showed a stronger identification (Mean $=0.5)$ with their local national park than non-users (Mean $=-0.4)(U=23,909, p$ $<0.001$; Table 2). In the multivariate analysis, local park users appeared to hold strong dependence with these places but the average sense of dependence among them was neutral $($ Mean $=0.0)$. Non-users were not dependent on these places $($ Mean $=-0.5)(\mathrm{U}$ $=19,114, \mathrm{p}<0.001$; Table 2, Figure 4a).

Among local national park users, those who frequently use these parks reported a higher level of identity $($ Mean $=0.7)$ than those who visit less often $($ Mean $=0.0)(\mathrm{U}$ $=11,319, \mathrm{p}<0.001 ;$ Cronbach's $\alpha=0.90$; Figure $4 \mathrm{~b})$. Frequent users reported almost neutral $($ Mean $=0.1)$ sense of dependence, while non-frequent users tended not to have a sense of dependence with their local park (Mean $=-0.4)(U=10,053, p<$ 0.001 ; Figure $4 b)$. 


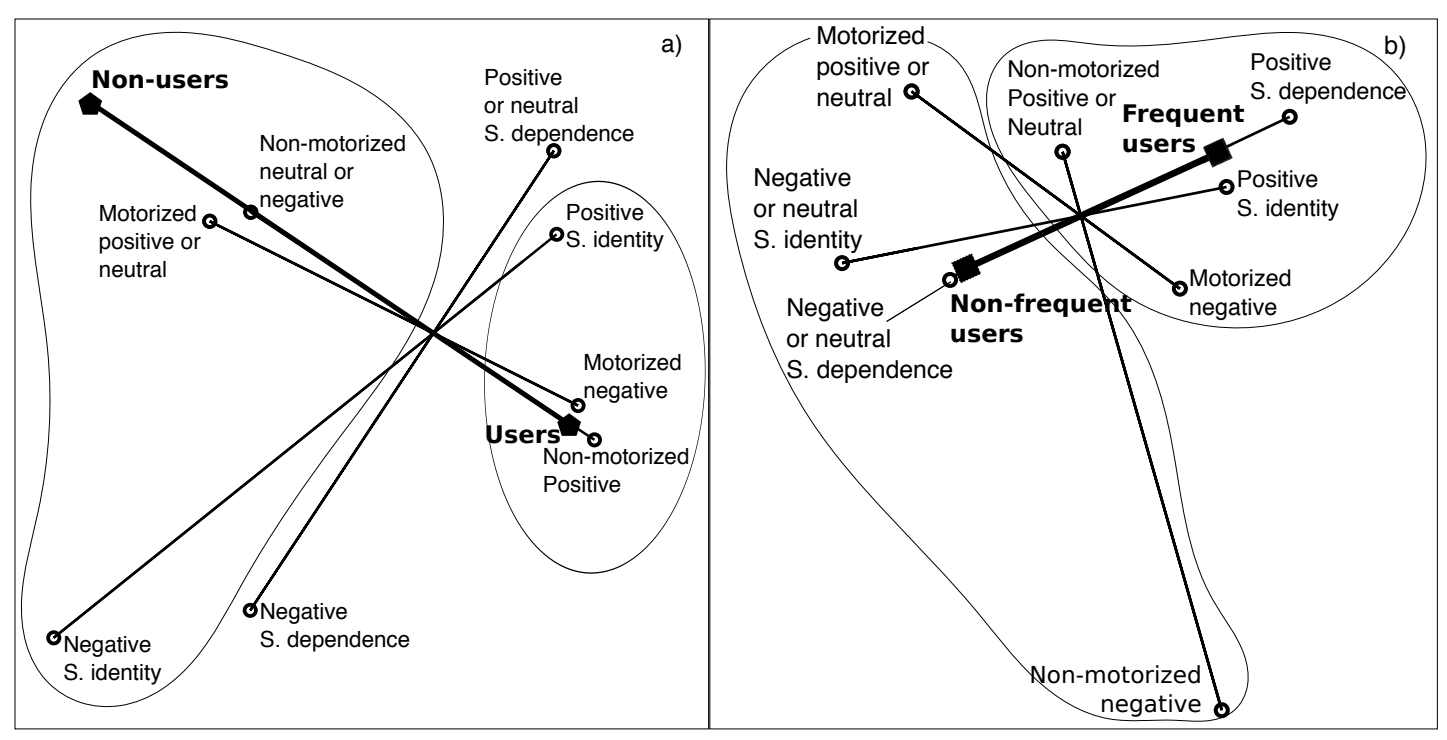

Figure 4. Categorical principal component analysis of a) users vs non-users and b) frequent vs non-frequent users analyzing sense of place and perceptions about their local national park in South East Queensland, Australia. The projection of the variables shows the relationship among them, with variables close together positively related and variables at $90^{\circ}$ angle not related to each other. $\mathrm{S}=$ sense

\section{Perceptions of recreational activities}

Respondents' perceptions of recreational activities in their local national park differed between users and non-users of the parks (Table 3). Park users were more positive about non-motorized activities $($ Mean $=0.5)$ than locals who never used their local national park $($ Mean $=0.1)(U=19,969, p<0,001$; Figure 4a). For example, users had more positive perceptions of hiking, running and picnicking than non-users (Table 3). For mountain bike riding, horse riding and dog walking, no significant differences were found between the perceptions of users and non-users (Table 3). In contrast, park users perceived motorized activities more negatively (Mean $=-1.09$ ) than non-users $($ Mean $=-0.5)(U=9,130, p<0,001$; Figure 4a).

Perhaps unsurprisingly, the frequency with which users visited their local national park influenced their perceptions of non-motorized activities $(U=19,969, p=0.031)$. Frequent users were slightly more positive (Mean $=0.5$ ) about non-motorized activities than non-frequent users (Mean $=0.3$; Figure $4 \mathrm{~b}$ ). Both user groups however, were equally negatively affected by motorized activities, including trail bike riding and four wheel driving (Mean $=-1.1)(U=9,130, p=0.890$; Figure 4b).

Users and non-users attributed a wide range of impacts to motorized activities (Figure 5a). For example, 49 per cent and 46 per cent of the total impacts were attributed to 
trail bike riding and four-wheel driving, respectively. Fewer than 20 per cent of the impacts selected were attributed to any non-motorized activity (Figure 5a). Local national park users perceived more social and environmental impacts than non-users for all recreational activities (Table 4). Many users reported potential collision or injury $(65 \%)$, too much noise $(67 \%)$, frightening wildlife $(63 \%)$, damage to plants or animals $(63 \%)$ and startling people $(45 \%)$ as the main impacts of recreational activities (Figure 5b). In addition, traffic, animal waste, and littering were also reported, but to a lesser extent (Table 4, Figure 5b).

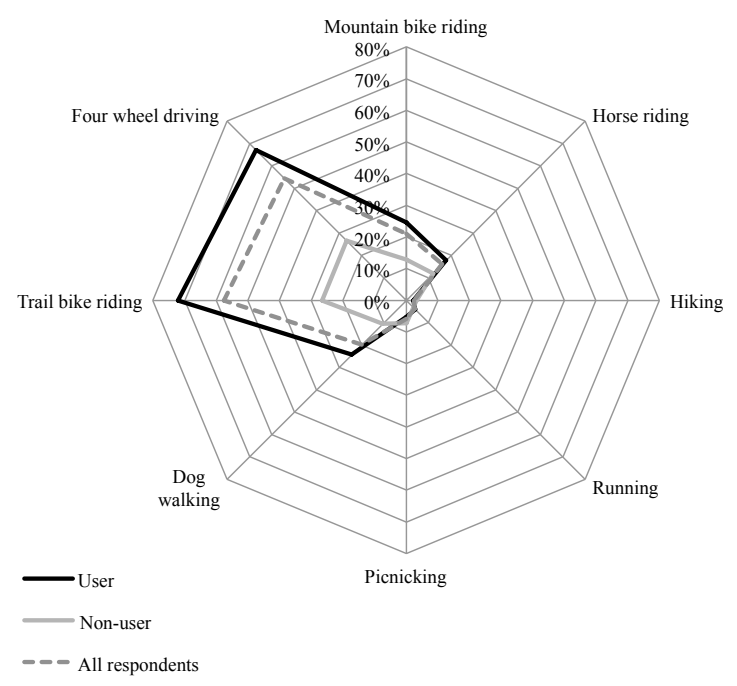

b)

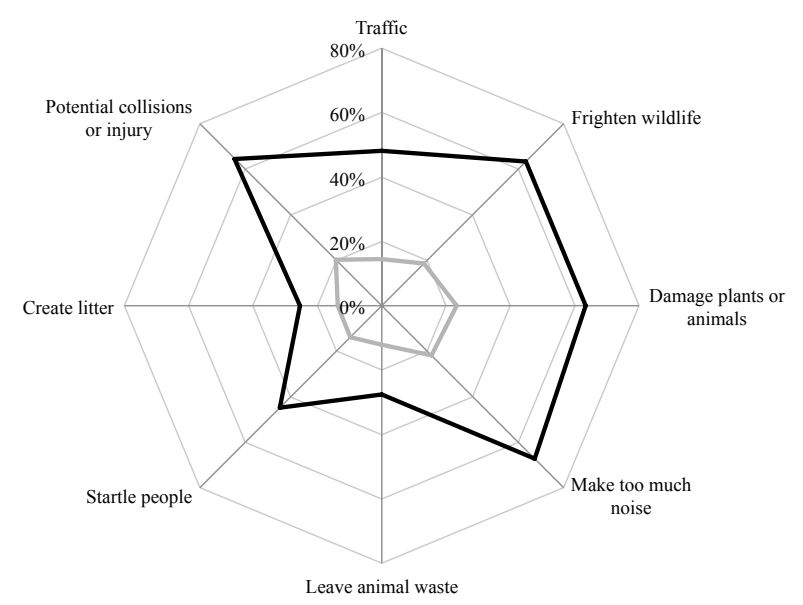

Figure 5. Percentage of respondents reporting their perceptions about a) recreational activities that cause social and environmental impacts and $b$ ) the impacts caused by recreational activities. 
Table 4. Perceptions of the local communities near six national parks in South East Queensland about social and environmental impacts of recreational activities, including motorized and non-motorized.

\begin{tabular}{lll}
\hline & Users & Non-users \\
Traffic & $129(48 \%)$ & $18(15 \%)$ \\
Frighten wildlife & $170(63 \%)$ & $23(19 \%)$ \\
Damage plants or animals & $170(63 \%)$ & $29(23 \%)$ \\
Make too much noise & $180(67 \%)$ & $27(22 \%)$ \\
Leave animal waste & $74(28 \%)$ & $15(12 \%)$ \\
Startle people & $120(45 \%)$ & $17(14 \%)$ \\
Create litter & $68(25 \%)$ & $17(14 \%)$ \\
Potential collisions or injury & $173(65 \%)$ & $25(20 \%)$ \\
\hline
\end{tabular}

\section{Discussion}

This study opens up new dimensions of understanding of national park visitation by examining two aspects of peri-urban national parks: (i) local residents' perceptions of the appropriateness of different recreational activities in peri-urban national parks and (ii) how local residents' sense of place influenced their perceptions of park use opportunities. Results indicate that survey respondents living in neighborhoods in close proximity to these national parks (hereafter termed local communities), perceive non-motorized activities as more appropriate uses for peri-urban national parks. These residents also consider motorized activities to be inappropriate activities in these settings and as not belonging in national parks. Also, as expected, these residents' sense of place towards peri-urban national parks influenced their perceptions of the acceptability of different types of recreational activities in these parks.

\section{How do local communities perceive recreational activities?}

This study found that local communities' perceptions were overall positive for a range of non-motorized recreational activities, including mountain bike riding and horse riding, regarded sometimes as controversial activities (Newsome, et al. 2013, Pickering, et al. 2011). In contrast, respondents reported negative perceptions of motorized activities including trail bike riding and four wheel driving. These results are similar to the on-site surveys of visitors conducted in the same six parks, where visitors reported that they were negatively affected by motorized activities, but positively affected by non-motorized activities including mountain bike riding and horse riding (Rossi, et al. 2013). 
In a more broadly based phone survey of all of Queensland where 1,003 people were surveyed (Newspoll 2012), fewer people felt negatively affected by motorized activities compared to the park visitor and local community surveys. This may reflect less knowledge and experience of motorized activities within parks in the broader Queensland community, among other factors. Supporting the results of our study, previous research has found that conflict can arise between recreationists who depend on technology (e.g. trail bikers) and those who do not (e.g. walkers) (Bury et al. 1983). Examples of other place-based conflicts elsewhere include between skiers and snowmobilers (Vaske, et al. 2007) and hikers and trail bike riders (Goeft \& Alder 2001).

\section{How do perceptions of recreational activities differ, based on park usage?}

In our study most respondents reported visiting their local national park, with 70 per cent visiting at least five times a year. Similarly, the on-site visitor surveys found that most visitors were locals (Rossi, et al. 2013). These results support many other studies internationally and nationally, including local communities surrounding protected areas in North Zürich, Switzerland (Frick, et al. 2007), in Southern California, USA (Byrne, et al. 2009) and in the World Heritage Sites in North Queensland (Bentrupperbäumer \& Reser 2008), which found that many people visit their local protected areas. Lawton \& Weaver (2008), however, found the opposite, with few people visiting their local protected area in South Carolina in the USA. These studies suggested that factors influencing non-visitation could include intrapersonal constraints, such as perceptions of crowding (Arnberger \& Brandenburg 2007, Lawton \& Weaver 2008), time and access constraints (Byrne, et al. 2009) or even perceptions of racism (Byrne 2012), resulting in the displacement of local park visitors.

For the areas surveyed in this study, it is likely that there is limited displacement of local residents due to park-based recreational activities. For example, respondents who used their local national park infrequently, or did not use them, seem to be less negatively affected by recreational activities than those who frequently used the periurban parks. Respondents who frequently used their local national park had stronger negative perceptions of motorized activities than those who used these parks less frequently, as well as non-users. This suggests that there may be other factors preventing people from using their local national parks, such as age, time and 
accessibility constraints (Byrne, et al. 2009), their orientation towards nature (Lin \& Lockwood 2014) or their attitudes, such as sense of place, towards their local protected area (Kaltenborn 1998, Kyle, et al. 2004).

\section{How do local communities' sense of place and socio-demographic characteristics influence their perceptions?}

In this study, residents' 'sense of place' influenced their perceptions of activities occurring within their local national park. Those reporting a stronger sense of place were more negatively affected by some recreational activities and their perceived impacts. This suggests that sense of place may be an influential factor shaping the perceptions of local communities about social and environmental impacts (Kaltenborn 1998).

These results support expected findings based on the social judgment theory which contends that attitudes such as sense of place can influence perceptions (Jorgensen \& Stedman 2001, Kyle, et al. 2004). For instance, respondents with a stronger sense of identity with their peri-urban national park reported more negative perceptions of motorized activities than respondents with a weaker sense of identity. This is similar to the results of a study of users of the Appalachian National Scenic Trails in the USA where those who more strongly identified with the trails reported stronger negative perceptions of social and environmental impacts such as 'crowding', 'improper visitor behaviors', environmental issues and 'user conflicts' (Kyle, et al. 2004). This suggests that people who identify with their local national park may have a small 'latitude of acceptance' for certain recreational activities such as trail bike riding and/or inappropriate visitor behavior in national parks.

In addition to the relationship between sense of place and perceptions found in this study, age also influences people's perceptions, consistent with the findings from environmental psychology research (Hidalgo \& Hernandez 2001, Jorgensen \& Stedman 2006). Older people may develop a stronger affinity for particular places, especially their house and surrounding areas (Jorgensen \& Stedman 2006). We found older people were more negatively affected by motorized activities than younger people. This could be attributed to their greater affinity for their local national park. More research is required however, to test this relationship as well as the relationship between sex and sense of place. For example, in this study, sex was found to influence people's sense of place, with women reporting stronger sense of place. This 
contradicts other studies that found no relationship between sense of place and sex (Lewicka 2010) or even the opposite with women reporting less sense of placedependence (Sutton 2009). Future studies should assess how factors such as sex, age and length of residence moderate the influence of sense of place on local community perceptions about recreational activities and their social and environmental impacts in peri-urban national parks.

\section{Policy implications}

Jorgensen and Stedman (2006, p. 317) noted that place-based attitudes have “implications for the public's acceptance of management strategies aimed at addressing particular environmental problems". The results of this study have some important policy implications.

Although some recreational activities, such as mountain bike riding and horse riding, are controversial activities in some protected areas (Newsome, et al. 2013, Pickering, et al. 2011), respondents in our study appeared to find them acceptable in the periurban national parks we assessed. This might be attributable to the policy-context in which these protected areas were created, or could be due to their peri-urban location and the characteristics of the populations these parks serve.

Many of the protected areas we assessed were previously managed for commercial purposes, such as forestry, and have only recently been upgraded to national park status (DERM 2011). This change in status affected some recreational activities permitted in the parks and on park trails. While recreational activities such as horse riding, four wheel driving and trail bike riding are still permitted, this is only on some designated trails classified as 'Forest Reserve' not 'National Park'. This could create conflict between recreationists pursuing more traditionally low-impact recreational activities (e.g. hiking or bird watching) and those engaged in motorized activities. The changes in status and the peri-urban location appear to affect respondents' perceptions of the appropriate use of these national parks.

Most respondents reported negative perceptions of trail bike riding and four wheel driving. This suggests that the level of acceptance or perceived appropriateness of recreational activities can vary depending on the geographic context in which national parks are located. In the peri-urban national parks we studied, local communities appear to have an explicit set of expectations that may differ from visitors' expectations about remote national parks. These expectations have important 
implications for park managers who may need to promote peri-urban national parks according to the current protection status and to the expectations of local communities and park visitors. Greater awareness is needed about the new status of these periurban national parks and associated park management regulations. This includes providing: (i) better signage at park entrances, (ii) enhanced information through official websites and (iii) increased park patrolling to restrict motorized activities to gazetted areas. Feedback to decision-makers about which activities local communities regard as 'off limits' in national parks could help to minimize potential conflicts and enhance visitors' experiences.

\section{Conclusions}

Understanding the local community usage of a national park, local residents' sense of place, and their perceptions of appropriate activities in national parks can potentially help protected area managers to reduce visitor-conflict and concomitant social and environmental impacts (Tanner-McAllister, et al. 2014). By understanding visitors' and local residents' attitudes and perceptions, managers could identify those people who are more likely to be affected by certain recreational activities, and then design appropriate interventions.

This study has shown that local communities near the peri-urban national parks we assessed have clear expectations that motorized recreational activities do not belong in national parks. The results of this study have important implications for park management, because they empirically establish an 'acceptability threshold' for different recreational activities in the peri-urban national parks we studied. The method applied here could be used in other settings to help determine their recreational activity acceptability thresholds. Future research is needed to test the utility of this method in other peri-urban national parks in Australia and internationally. 


\section{References}

ABS (Australian Bureau of Statistics) 2014, Queensland regional profiles, ABS, Canberra, viewed September 15th 2014, <http://statistics.oesr.qld.gov.au/qldregional-profiles?region-type $=$ RPA\&region-ids $=19159 \% 3 \mathrm{E}$.

Ajzen I \& Fishbein M 1977, 'Attitude-behavior relations: A theoretical analysis and review of empirical research', Psychological Bulletin, Vol. 84, pp. 888-918.

Arnberger A \& Brandenburg C 2007, 'Past on-site experience, crowding perceptions, and use displacement of visitor groups to a peri-urban national park', Environmental Management, Vol. 40, pp. 34-45. doi: 10.1007/s00267-0040355-8

Arnberger A \& Haider W 2005, 'Social effects on crowding preferences of urban forest visitors', Urban Forestry and Urban Greening, Vol. 3, pp. 125-136.

Axelrod L 1994, 'Balancing personal needs with environmental preservation: Identifying the values that guide decisions in ecological dilemmas', Journal of Social Issues, Vol. 50, pp. 85-104.

Balmford A, Beresford J, Green J, Naidoo R, Walpole M \& Manica A 2009, 'A global perspective on trends in nature-based tourism', PLoS Biology, Vol. 7, pp. e1000144.

Bentrupperbäumer JM \& Reser J 2008. 'Encountering a world heritage landscape: Community and visitor perspectives and experiences'. in N Stork \& S Turton (Eds.), Living in a Dynamic Tropical Forest Landscape: Lessons from Australia, Blackwell Publishing, Oxford.

Bury RL, Holland SM \& McEwen DN 1983, 'Analyzing recreational conflict', Journal of Soil and Water Conservation, Vol. 38, pp. 401-403.

Buttimer A \& Seamon D 1980, The Human Experience of Space and Place, Croom Helm, London.

Byrne J 2012, 'When green is white: The cultural politics of race, nature and social exclusion in a Los Angeles urban national park', Geoforum, Vol. 43, pp. 595611. doi: http://dx.doi.org/10.1016/j.geoforum.2011.10.002

Byrne J, Wolch J \& Zhang J 2009, 'Planning for environmental justice in an urban national park', Journal of Environmental Planning and Management, Vol. 52, pp. 365-392.

DERM (Department of Environment and Resource Management) 2011, South East Queensland Horse Riding Trail Network: Management plan, Queensland Government, Brisbane.

Dietz T, Fitzgerald A \& Shwom R 2005, 'Environmental values', Annual Review of Environment and Resources, Vol. 30, pp. 335-372. doi: doi:10.1146/annurev.energy.30.050504.144444

Dillman DA 2007, Mail and Internet Surveys: The Tailored Design Method, John Wiley \& Sons, Hoboken.

Fazio RH 1990, 'Multiple processes by which attitudes guide behavior: The MODE model as an integrative framework', Advances in Experimental Social Psychology, Vol. 23, pp. 75-109.

Fazio RH \& Williams CJ 1986, 'Attitude accessibility as a moderator of the attitudeperception and attitude-behavior relations: An investigation of the 1984 presidential election', Journal of Personality and Social Psychology, Vol. 51, pp. 505-514.

Fishbein M 1963, 'An investigation of the relationship between beliefs about an object and the attitude toward that object', Human Relations, Vol. 16, pp. 233-239. doi: 10.1177/001872676301600302 
Fishbein M \& Ajzen I 1975, Belief, Attitude, Intention and Behavior: An Introduction to Theory and Research, Addison-Wesley, Boston.

Frick J, Degenhardt B \& Buchecker M 2007, 'Predicting local residents' use of nearby outdoor recreation areas through quality perceptions and recreational expectations', Forest Snow and Landscape Research, Vol. 81, pp. 31-41.

Goeft U \& Alder J 2001, 'Sustainable mountain biking: A case study from the southwest of Western Australia', Journal of Sustainable Tourism, Vol. 9, pp. 193-211. doi: 10.1080/09669580108667398

Haugen K \& Vilhelmson B 2013, 'The divergent role of spatial access: The changing supply and location of service amenities and service travel distance in Sweden', Transportation Research Part A: Policy and Practice, Vol. 49, pp. 10-20.

Healy S 2009, Urban nature parks - Their use and management: A Karawatha Forest Park case study. (Bachelor of Science Honours), Griffith University, Gold Coast.

Hidalgo MC \& Hernandez B 2001, 'Place attachment: Conceptual and empirical questions', Journal of Environmental Psychology, Vol. 21, pp. 273-281.

Hofmann M, Westermann JR, Kowarik I \& van der Meer E 2012, 'Perceptions of parks and urban derelict land by landscape planners and residents', Urban Forestry \& Urban Greening, Vol. 11, pp. 303-312.

Hsu CH, Cai LA \& Li M 2010, 'Expectation, motivation, and attitude: A tourist behavioral model', Journal of Travel Research, Vol. 49, pp. 282-296.

Inglis J, Deery M \& Whitelaw PA 2008, The Development of Place Attachment in Parks. Cooperative Research Centre for Sustainable Tourism Pty. Ltd., Gold Coast

Jorgensen BS \& Stedman RC 2001, 'Sense of place as an attitude: Lakeshore owners attitudes toward their properties', Journal of Environmental Psychology, Vol. 21, pp. 233-248.

Jorgensen BS \& Stedman RC 2006, 'A comparative analysis of predictors of sense of place dimensions: Attachment to, dependence on, and identification with lakeshore properties', Journal of Environmental Management, Vol. 79, pp. 316-327. doi: http://dx.doi.org/10.1016/j.jenvman.2005.08.003

Jurowski C \& Gursoy D 2004, 'Distance effects on residents' attitudes toward tourism', Annals of Tourism Research, Vol. 31, pp. 296-312.

Kaltenborn BP 1998, 'Effects of sense of place on responses to environmental impacts: A study among residents in Svalbard in the Norwegian high Arctic', Applied Geography, Vol. 18, pp. 169-189.

Knafo A, Roccas S \& Sagiv L 2011, 'The value of values in cross-cultural research: A special issue in honor of Shalom Schwartz', Journal of Cross-Cultural Psychology, Vol. 42, pp. 178-185. doi: 10.1177/0022022110396863

Kyle G, Absher JD \& Graefe AR 2003, 'The moderating role of place attachment on the relationship between attitudes toward fees and spending preferences', Leisure Sciences, Vol. 25, pp. 33-50.

Kyle G, Graefe A, Manning R \& Bacon J 2004, 'Effects of place attachment on users' perceptions of social and environmental conditions in a natural setting', Journal of Environmental Psychology, Vol. 24, pp. 213-225.

Larson S, De Freitas DM \& Hicks CC 2013, 'Sense of place as a determinant of people's attitudes towards the environment: Implications for natural resources management and planning in the Great Barrier Reef, Australia', Journal of Environmental Management, Vol. 117, pp. 226-234. 
Lawton LJ \& Weaver DB 2008, 'Factors associated with non-visitation by area residents to Congaree National Park, South Carolina', Journal of Park and Recreation Administration, Vol. 26, pp. 66-82.

Lee TH 2011, 'How recreation involvement, place attachment and conservation commitment affect environmentally responsible behavior', Journal of Sustainable Tourism, Vol. 19, pp. 895-915.

Lemberg D 2010. 'Environmental perception'. in B Warf(Ed.), Encyclopedia of Geography, Sage, Thousand Oaks.

Lewicka M 2010, 'What makes neighborhood different from home and city? Effects of place scale on place attachment', Journal of Environmental Psychology, Vol. 30, pp. 35-51. doi: http://dx.doi.org/10.1016/j.jenvp.2009.05.004

Lewicka M 2011, 'Place attachment: How far have we come in the last 40 years?', Journal of Environmental Psychology, Vol. 31, pp. 207-230.

Lin C-C \& Lockwood M 2014, 'Assessing sense of place in natural settings: A mixedmethod approach', Journal of Environmental Planning and Management, Vol. 57, pp. 1441-1464. doi: 10.1080/09640568.2013.811401

Linting M, Meulman JJ, Groenen PJ \& Van der Kooij AJ 2007, 'Nonlinear principal components analysis: Introduction and application', Psychological Methods, Vol. 12, pp. 336-358.

Lockwood M, Worboys G \& Kothari A 2006, Managing Protected Areas: A Global Guide, Earthscan, London.

Newsome D, Moore SA \& Dowling RK 2013, Natural Area Tourism: Ecology, Impacts and Management, Channel View Publications, New York.

Newspoll 2012, QPWS Community Survey 2012 . Part 3, Horse Trail Network. Newspoll House, Surry Hills

O'Keefe PA 2008, 'Social Judgment Theory', in WA Darity (Ed.) International Encyclopedia of the Social Sciences, Macmillan, Detroit.

Peschardt KK, Schipperijn J \& Stigsdotter UK 2012, 'Use of small public urban green spaces (SPUGS)', Urban Forestry and Urban Greening, Vol. 11, pp. 235-244. doi: http://dx.doi.org/10.1016/j.ufug.2012.04.002

Pickering CM, Rossi SD \& Barros A 2011, 'Assessing the impacts of mountain biking and hiking on subalpine grassland in Australia using an experimental protocol', Journal of Environmental Management, Vol. 92, pp. 3049-3057.

QDNRM (Queensland Department of Natural Resources and Mines) 2012, Locality boundaries - Queensland shapefile, State of Queensland,Brisbane.

Relph E 1976, Place and Placelessness, Pion, London.

Reser JP \& Bentrupperbäumer JM 2005, 'What and where are environmental values? Assessing the impacts of current diversity of use of 'environmental' and 'World Heritage' values', Journal of Environmental Psychology, Vol. 25, pp. 125-146. doi: http://dx.doi.org/10.1016/j.jenvp.2005.03.002

Rossi SD, Byrne JA \& Pickering CM 2015, 'The role of distance in peri-urban national park use: Who visits them and how far do they travel?', Applied Geography, Vol. 63, pp. 77-88. doi: http://dx.doi.org/10.1016/j.apgeog.2015.06.008

Rossi SD, Byrne JA, Pickering CM \& Reser J 2015, 'Seeing red' in national parks: How visitors' values affect perceptions and park experiences', Geoforum, Vol. 66, pp. 41-52. doi: http://dx.doi.org/10.1016/j.geoforum.2015.09.009.

Rossi SD, Pickering CM \& Byrne JA 2013, Attitudes of Local Communities: Assessing the Social Impacts of the South East Queensland Horse Riding Trail Network. Queensland Government, Brisbane 
Rossi SD, Pickering CM \& Byrne JA 2013, Attitudes of Local Park Visitors: Assessing the Social Impacts of the South East Queensland Horse Riding Trail Network. Queensland Government, Brisbane

Schwartz SH 1994, 'Are there universal aspects in the structure and contents of human values?', Journal of Social Issues, Vol. 50, pp. 19-45. doi: 10.1111/j.15404560.1994.tb01196.x

Sherif M \& Cantril H 1947, The Psychology of Ego-Involvement, John Wiley and Sons, New York.

Sherif M \& Hovland CI 1961, Social Judgment: Assimilation and Contrast Effects in Communication and Attitude Change, Yale University Press, Oxford.

Stedman RC 2002, 'Toward a social psychology of place predicting behavior from place-based cognitions, attitude, and identity', Environment and Behavior, Vol. 34, pp. 561-581.

Sutton M 2009, Measuring environmental perceptions and sense of place in Franklin County, Florida. (Master of Science Degree), Ball State University, Muncie.

Tanner-McAllister S, Rhodes J \& Hockings M 2014, 'Community and park manager's perceptions of protected area management: A southeast Queensland study', Australasian Journal of Environmental Management, Vol. 21, pp. 320-336.

Tuan Y-F 1974, Topophilia, Prentice-Hall, New York.

Tuan Y-F 1977, Space and Place: The Perspective of Experience, University of Minnesota Press, Minneapolis.

Tuan Y-F 1980, 'Rootedness versus sense of place', Landscape, Vol. 24, pp. 3-8.

Vaske JJ, Needham MD \& Cline R 2007, 'Clarifying interpersonal and social values conflict among recreationists', Journal of Leisure Research, Vol. 39, pp. 182195.

Veal AJ 2011, Research Methods for Leisure and Tourism: A Practical Guide, Pearson Education, Harlow.

Williams DR \& Vaske JJ 2003, 'The measurement of place attachment: Validity and generalizability of a psychometric approach', Forest Science, Vol. 49, pp. 830840.

Worboys G, Lockwood M, Kothari A, Feary S \& Pulsford I 2015, Protected Areas Governance and Management, ANU Press, Canberra.

Zanon D, Doucouliagos C, Hall J \& Lockstone-Binney L 2013, 'Constraints to park visitation: A meta-analysis of north american studies', Leisure Sciences, Vol. 35, pp. 475-493. 